\title{
The Determinants of E-Relationship Quality on E-Satisfaction In Hotel Websites
}

\author{
Ali Af. Asgari ${ }^{1}$, Abu Bakar Abdul Hamid ${ }^{2,}$ Azadeh Asgari ${ }^{3}$ Seyedhamed \\ Mousavipour $^{4}$ \\ ${ }^{1}$ Faculty of Management and Human Resource Development, Universiti Teknologi Malaysia, \\ ${ }^{2}$ Faculty of Management and Human Resource Development, Universiti Teknologi Malaysia, \\ ${ }^{3}$ Faculty of Educational Studies, University Putra Malaysia, \\ ${ }^{4}$ Faculty of Engineering, Islamic Azad University (Najafabad Branch),
}

\begin{abstract}
This study aims to investigate the determinants of e-relationship quality on e-satisfaction in Malaysian hotel websites. The objectives of this study are to investigate the association between determinants of e-relationship quality and e-satisfaction. This research adopts the quantitative method (correlational design) so that the questionnaire could be sent to a large number of informants, making the collection of great samples feasible. The researcher gathered data through survey and used close coding to code the data as well as constant comparative methods to analyze them. In addition, based on the aim of this study, 150 respondents were randomly selected by using the accidental sampling method comprised of Malaysian adult male and female with age ranging from 25 to above 65 years old. This survey was conducted in Malaysian hotels which are located in Kelang Valley. The findings revealed that the communicational function, followed by relational function and transactional function was the most important dimensions that would affect customer esatisfaction. Furthermore, the findings of this study indicated that there is a positive relationship between the erelationship quality and e-satisfaction.
\end{abstract}

Keyword-e-relationship quality, e-satisfaction, Hotel website

\section{Introduction}

The Internet was created in 1969, during the Cold War by the United States military (Odlyzko, 2000). Today, the Internet covers the globe and consists of innumerable networks and computers, which provide a platform for people to share information. In June 2010, 1,966,514,816 billion people have used the Internet worldwide while the Malaysian Internet users totaled 16,903,000 million people (InternetWorldStats, 2010). In addition, the growth rate of users in Malaysia from 2000 to 2010 equaled to $356.8 \%$ (InternetWorldStats, 2010). Consequently, many businesses have moved to the online world in order to cater for the global Internet population.

Among these Internet users, approximately 54.4 percent visited the Internet from the central region of Malaysia, followed by the rate of Internet usage in southern and northern areas of Malaysia with the same capacity (14.9 percent). This status is considerably diminished in Sabah and Sarawak (5.9 percent) and just 4 percent of people who live in the East Coast use the Internet for searching information and planning their travels (comScore, 2010).

\section{II. e-Relationships Quality}

The relationship marketing paradigm has been a popular topic in marketing and management research. The principle of this paradigm is on how an organization can enhance customer satisfaction through the relationship. Gummesson (1987) was the early academician to introduce the topic of relationship quality, referring to it as the quality of the behavior between a company and its customers. The term of relationship quality was further defined by Hennig-Thurau \& Klee (1997) from the viewpoint of quality of interaction among company and customers.

Many researchers have explained quality of relationship as a higher order concept comprising of satisfaction (Lin \& Ding, 2005; Hennig-Thurau \& Klee, 1997; Crosby et al., 1990; Dwyer \& Oh 1987), trust (Dorsch et al., 1998; Bejou et al., 1996; Kumar et al., 1995; Wray et al., 1994 Moorman \& Zaltman, 1992; Crosby et al., 1990; Dwyer \& Oh 1987), commitment (Kumar et al., 1995; Crosby et al., 1990; Dwyer \& Oh, 1987), opportunity (Dorsch et al., 1998), and customer orientation (Bejou et al., 1998; Dorsch et al., 1998). 
Bejou et al., (1996) studied the association among salespeople and customers. Hence, relationship quality has been investigated in many contexts by many researchers.

In an offline background, the measurement of relationship quality has been summarized as_customer satisfaction (Dorsch et al., 1998; Hennig-Thurau \& Klee, 1997; Bejou et al., 1996; Kumar et al., 1995; Wray et al., 1994; Moorman \& Zaltman, 1992; Lagace, Dahlstrom, \& Gassenheimer, 1991; Crosby et al., 1990; Dwyer\& Oh, 1987).

Furthermore, Rauyruen (2007) proposed relationship quality as an extensive concept comprising of satisfaction, trust, commitment, and service quality in a business-to-business context that influences customer loyalty. In the literature, some of the authors pointed out that relationship quality has only two elements, satisfaction and trust (Rauyruen, 2007; Bejou et al., 1998; Dick \& Basu, 1994; Dwyer \& Oh, 1987). Therefore, this thesis proposes that relationship quality in an online context (e-relationship quality) includes two dimensions: online satisfaction (e-satisfaction) and online trust (e-trust).

\section{3. e-Satisfaction}

Oliver (1997) stated that customer satisfaction is to satisfy customer expectation by a company. In addition, Storbacka, Strandvik, \& Gronroos (1994) defined "customer satisfaction as customers' cognitive and affective measurement based on their individual experience across all service episodes within the relationship"(p. 25). Furthermore, Locklove, Patterson and Walker (1998) summarized the significance of customer satisfaction as follows: firstly, customer loyalty and relationship commitment are relevant to customer satisfaction. Secondly, a very satisfied customer spreads favorable word of mouth by praising the organization and the service with which he or she is very pleased with. In the affective phase of customer satisfaction, Oliver (1999) stated that customers hold a favorable commitment towards a brand/product. Lastly, Dwyer and Oh (1987) suggested that very satisfied customers can be forgiving when service failure happened and they express less negative world of month.

Customer satisfaction with a hotel website would be assessed by the level of user satisfaction with the hotel's website and the fulfillment of users' expectation. In contrast, a customer who is unsatisfied with a service supplier cannot expect to have a very good and close association with that provider. Lages et al. (2005) considered satisfaction with a relationship to be a prominent dimension of relationship quality.

Moreover, e-satisfaction happens when customers compare experience of online service with traditional offline service providers or retail stores (Evanschitzky, Iyer, Hesse, \& Ahlert, 2004; Szymanski \& Hise, 2000). Anderson and Srinivasan examined the effect of satisfaction on loyalty in the context of electronic business. They defined e-satisfaction as "the contentment of the customer with respect to his or her prior purchasing experience with a given electronic commerce firm" (2003, p.125). Besides, Szymanski and Hise (2000) conducted a study on e-satisfaction in which the conceptual framework of e-satisfaction was established in an e-retailing environment.

\section{Dimensions of Website Service Quality of a Hotel Website}

Several studies were dedicated to identifying the underlying dimensions of website service quality that directly affect customers e-satisfaction, customer e-trust, and customer e-loyalty (Ho \& Lee, 2007; Sanchez, Franco \& Roldan, 2005; Yang et al., 2005; Kim \& Lee, 2004; Wolfinbarger \& Gilly, 2003; Francis \& White, 2002a; Kaynama \& Black, 2000; Loiacono et al., 2002; Madu \& Madu, 2002; Yang \& Jun, 2002; Zeithaml et al., 2002; Yoo \& Donthu, 2001; Jeong \& Lambert, 2001). In accordance with the prior studies of website service quality dimensions, five attributes of website service quality have been identified in this thesis, as major elements of affecting website quality, including useful website content, website convenience, accessibility, website security, and website design (Jeon, 2009). These attributes were gathered under website service quality of the hotel website.

If a customer can obtain information through a hotel website in no time without having technical difficulties, that customer will move toward e-satisfaction and consequently, e-loyalty will be happened. A customer will perceive the service quality on a website based upon his/her experience related to website functionality.

A hotel website also contributes to the hotel's bottom line by saving labor costs. Through online searching hotels' information, customers can easily gather the necessary information on hotel such as service quality, location and tourist attractions without any connection to hotel staff directly (Jeon, 2009). Such online services do not only reduce phone calls from customers who seek information, but also reduce hotel employees' workload in answering telephone calls. Hence, employees can focus on servicing in-house guests or any other necessary tasks efficiently.

A lodging website, however, is a channel of e-commerce, where users rely on others' references and recommendations in their decision making procedure of purchases (Jeon, 2009). He added that it is logical to 
expect social influence affecting an e-commerce environment, and to investigate the impact of social influence on user behavior on a lodging website.

In accordance with the literature review, a conceptual framework of this study depicts the stages of how data is collected, analyzed and reviewed to form a basis of this thesis. Moreover, the conceptual model illustrates determinants of e-relationship quality and e-loyalty. The determinants of e-relationship quality in this model are communicational function, transactional function, and relational function.

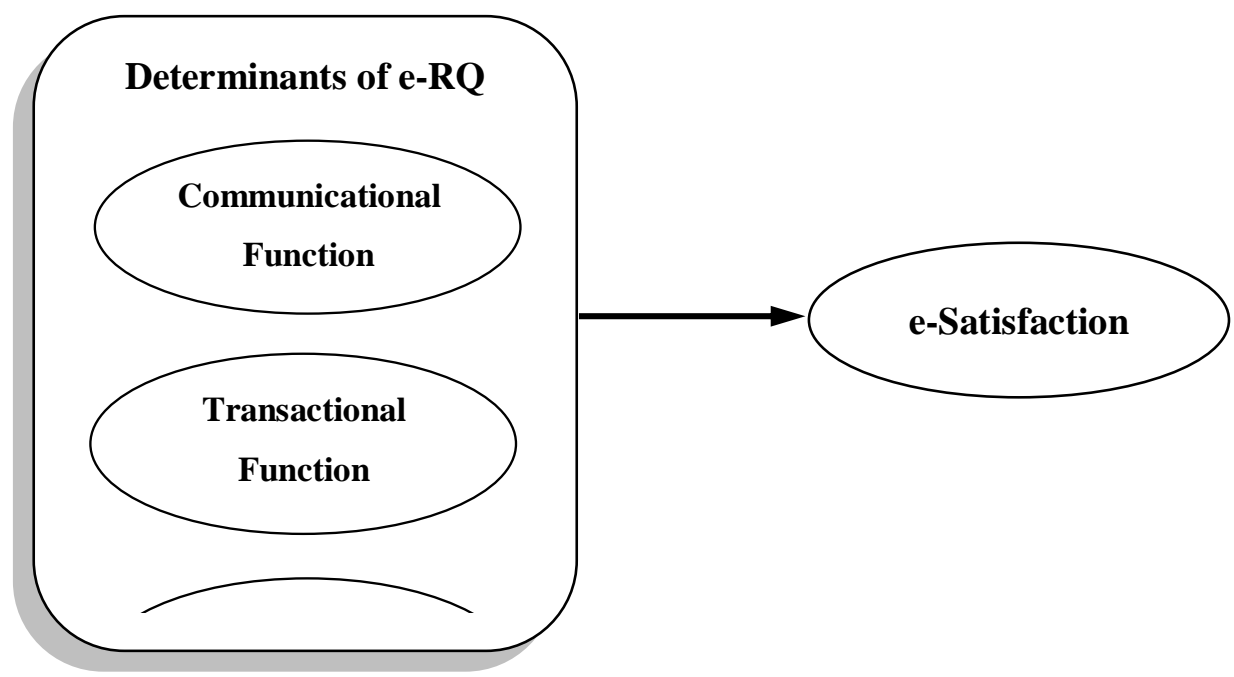

Figure 1. Proposed Model of the Determinants of e-Relationship Quality \& e-Loyalty

This study seeks to give a better understanding on the customer e-loyalty by analyzing the following research questions:

1. Whether the communicational function is positively related to the e-relationship quality?

2. Whether transactional function is positively related to e-relationship quality?

3. Whether relational function is positively related to the relationship quality?

4. Is there any significant relationship between the e-relationship quality and e-satisfaction?

\section{Methods \& Materials}

In accord with Babbie (2007), Correlational design was chosen in this research so that the questionnaire could be sent to a large number of informants, making the collection of great samples possible. Besides the type of research questions being posed in the present study, another equally important reason for using this research design was the collection of data from a relatively large number of subjects. The selfadministered questionnaire is conducted for exploratory, explanatory and descriptive purposes. They are chiefly applied in studies that have individual people as the units of analysis (Babbie, 2007). The main part of research instrument (exclude the demographic profile) including communicational function, transactional function, relational function, and e-satisfaction consisted of 26 items. The type of questionnaire that was employed in this thesis was the Likert scale, with five-point label, that had been applied with anchor from " $1=$ Strongly Agree to $5=$ Strongly Disagree". So each question has 5 possible responses ranging from 1 to 5 . Babbies (2007) noted that Likert scale questionnaire is very popular because such questions provide greater uniformity of responses. In addition, Wimmer and Dominick (2003) mentioned that Likert scales help to simplify the data analysis as the answers are easily quantified. This shall be useful to determine the correlation between the both independent and dependent variables mentioned in the hypotheses. Moreover, the reliability test was applied by calculating the Cronbach's Alpha on most variables to measure the inter-item reliability and indicating that the inter-items have high reliability.

This survey has been conducted on Malaysian hotel website. These hotels are located in Klang Valley, the area comprising of Kuala Lumpur and its suburbs. The subjects in this thesis consist of one hundred and fifty customers who have stayed at 5 star hotels during the fall season of 2010 in Klang Valley, Malaysia.

It is ranked among the best hotels in Malaysia and more focus was centered on five star hotels websites. The sampling type which has been conducted in this thesis is convenience sampling. That is to say that for the thesis, the sampling procedure was the customers from different five star hotels in Klang Valley. The subjects in this thesis consist of one hundred and fifty customers who have stayed at 5 star hotels during the fall season of 2010 in Klang Valley, Malaysia. 
The ultimate purpose of analyzing data is to rule out alternative interpretations, to produce compelling analytical conclusions and to treat the evidence fairly. Data analysis includes turning a series of recorded observation into descriptive and significant statements. In this thesis, the data gathered were entered and coded into the computer for analysis. They were interpreted with the Statistical Package for Social Sciences (SPSS) version 16 for Windows Vista Home Premium. Moreover, these analyses included both descriptive statistics and inferential statistics.

The research made extensive use of "Pearson Product Moment Correlation" of inferential statistics. Inferential analysis determines the strength of the relationship among dependent and independent variables. This method was applied to identify whether the correlation exist among the various dependent and independent variables.

\section{Results and Findings}

In response to the purpose of this study, the respondents reported that finding information relevant to research is most common among them. Correlation analysis was conducted on the hypotheses that configured the association between dimensions of e-relationship quality and the e-loyalty of a Malaysian hotel website.

Table 1. Correlations among dimensions of e-Relationship Quality and e-Satisfaction

\begin{tabular}{|c|c|c|c|c|}
\hline & CF & TF & RF & $e-S$ \\
\hline Communicational Function(CF) & 1.0 & & & \\
\hline Transactional Function(TF) & $.205^{-5-}$ & 1.0 & & \\
\hline Relational Function(RF) & $.338^{+27}$ & $.262^{-24}$ & 1.0 & \\
\hline e-Satisfaction(eS) & $.157^{4}$ & .121 & $.193^{24}$ & 1.0 \\
\hline
\end{tabular}

$\mathrm{n}=150$

Table 1. indicated that there exists a positive association among the RF and CF ( $r=.338$ ) rather than other items. Additionally, the correlation between CF and TF was low ( $r=.205)$, and there is also a low correlation between RF and TF ( $r=.262)$, TF and e-Trust $(r=.257)$, RF and e-Trust $(r=.242)$, e-Loyalty and CF $(r=.246)$, e-Loyalty and RF ( $r=.345)$, e-Loyalty and e-Satisfaction $(r=.206)$, and finally e-Loyalty and e-Trust $(r=.263)$. While a considerably negligible correlation was displayed among e-Satisfaction and Communicational Function $(r=.157)$, between e-Satisfaction and Transactional Function $(r=.121)$, and between e-Trust and Communicational Function ( $r=.116)$, among e-Satisfaction and e-Trust ( $r=.177)$ and lastly, between e-Loyalty and Transactional Function $(r=.143)$. Table 1 . summarized the correlations among variables.

The fourth and fifth research objectives are to examine the association between e-Relationship Quality (eRQ) on e-Satisfaction (eS) and e-Trust (eT). These research questions examined the following directional hypothesis: there are positive relationships between e-relationship quality (eRQ) on e-satisfaction (eS) and e-trust (eT) at .05 level of significant.

Table 2. Relationship among e-Relationship Quality and e-Satisfaction and e-Trust

\begin{tabular}{lc}
\hline & e-Satisfaction \\
\hline e-Relationship Quality(eRQ) & $.712^{* *}$ \\
$* *$. Correlation is significant at the 0.01 level (1-tailed). & \\
$*$. Correlation is significant at the 0.05 level (1-tailed).
\end{tabular}

To investigate these research questions, the Pearson Product Moment Correlation was used to determine the association between purpose of (eRQ) on e-satisfaction (eS) and e-trust (eT) to detect the relationships among them. The following table provides the inferential statistics of the eRQ on eS and eT at .05 level of significant.

The results in the following table revealed that there are high positive and significant associations among e-relationship quality (eRQ) and e-Satisfaction (eS) and e-Trust (eT), as follows: e-relationship quality and e-satisfaction $(r=.712, p>.01)$, as well as e-relationship quality and e-trust $(r=.817, p>.01)$. In general, the associations among e-Relationship Quality and e-Satisfaction and e-Trust are significant and of very high relationships. Moreover, there is also a significant correlation among e-satisfaction (eS) and e-trust (eT) as displayed in the above table (Table 2.).

Based on this conclusion, therefore, it is affirmed that the hypothesis 4 and 5 are accepted at the .05 level of significant. In overall, the results of this thesis demonstrated that the respondents were satisfied with 
using hotel websites and this result is supported by Lages et al., (2005) that considered the relationship among esatisfaction and e-trust to be a key dimension of e-relationship quality.

\section{7. Conclusion}

The rising of online computing technology rates' makes it an essential factor for businesses to seriously consider the Internet to prevent from losing this competitive advantage. A website gives direct links among the consumer and the organization (Kiang et al., 2000). Thus, many prior researches on the determinants of erelationship quality have suggested that the e-relationship quality are combinations of technical functions like Internet security and traditional communicational function in marketing like mailing services (Devaraj et al., 2006; Bart et al., 2005; Kim et al., 2001). In light of the first issue, the determinants of e-relationship quality were revealed to have three aspects: communicational function, transactional function, and relational function.

The results displayed that the communicational function, followed by relational function and transactional function were the most important dimension that would be affected customer e-loyalty. Firstly, the traditional communicational function concentrates on common interaction among a firm and customers in marketing. This function continues to perform a prominent role in the online context due to an online provider is in a better position to take advantage of the Internet for disseminating information as well as answering all inquiries from customers. Secondly, considering the relative influence of the transactional function, the dominant factor of transactional function was website service quality related to the useful website content, content website convenience, website accessibility, website security, and website design followed by transaction complexity. Thirdly, the relational function included customized service and personalized WebPages. Personalized hotel website is a prominent characteristic that can allow hotel guests to report personal needs, complaints and suggestions.

Therefore, in order to have a competitive advantage, a hotel provider should offer services/products via the website with active communicational interaction, low transaction complexity and high customization.

\section{REFERENCES}

[1] Anderson, R. E. \& Srinivasan, S. S. (2003). E-satisfaction and e-loyalty: A contingency framework. Psychology \& Marketing, 20, 123-138.

[2] Ary, D., Jacobs, L. C. (2006). Introduction to research in education ( $7^{\text {th }}$ ed.). New York: Holt, Rinehart and Winston.

[3] Babbie .E.(2007).The practise of social research. $7^{\text {th }}$ ed. Belmont: Wadsworth Publishing Co.

[4] Bart, Y., Shankar, V., Sultan, F., \& Urban, G. L. (2005). Are the drivers and role of online trust the same for all web sites and consumers? A large-scale exploratory empirical study. Journal of Marketing, 69(4), 133-152.

[5] Bejou, D., Ennew, C. T., \& Palmer, A. (1998). Trust, ethics and relationship satisfaction. International Journal of Bank Marketing, 16(4), 170-175.

[6] Bejou, D., Wray, B., \& Ingram, T. N. (1996). Determinants of relationship quality: An artificial neural network analysis. Journal of Business Research, 36(2), 137-143.

[7] ComScore. (2007). Malaysian Internet Usage Driven Primarily by People in Central Region. Retrieved December 1, 2010 ,

from http://www.comscore.com/Press_Events/Press_Releases/2010/10/comScore_Expands_Segmentation_Capabilities_i n_Malaysia

[8] Crosby, L. A., Evans, K. R., \& Cowles, D. (1990). Relationship quality in service selling: An interpersonal influence perspective. Journal of Marketing, 54, 68-81.

[9] Devaraj, S., Fan, M., \& Kohli, R. (2006). Examination of online channel preference: Using the structure-conductoutcome framework. Decision Support Systems, 42(2), 1089.

[10] Dick, A. S., \& Basu, K. (1994). Customer loyalty: Toward an integrated conceptual framework. Journal of the Academy of Marketing Science, 22(2), 99-113.

[11] Dorsch, M. J., Swanson, S. R., \& Kelley, S. W. (1998). The role of relationship quality in the stratification of vendors as perceived by customers. Journal of the Academy of Marketing Science, 26(2), 128-142.

[12] Dwyer, F. R., \& Oh, S. (1987). Output sector munificence effects on the internal political economy of marketing channels. Journal of Marketing Research, 24, 347-358.

[13] Evanschitzky, H., Iyer, G. R., Hesse, J., \& Ahlert, D. (2004). E-satisfaction: A reexamination. Journal of Retailing, 80(3), 239-247.

[14] Francis, J., \& White, L. (2002a). PIRQUAL: A scale for measuring customer expectations and perceptions of quality in Internet retailing. In Evans, K. \& Scheer L. (Eds). Proceedings of the 2002 American marketing association winter educators' conference: Marketing theory and applications. American Marketing Association, 13, 263-270.

[15] Gummesson, E. (1987). The new marketing: Developing long-term interactive relationships. Long Range Planning, 20(4), 10-21.

[16] Hennig-Thurau, T., \& Klee, A. (1997). The impact of customer satisfaction and relationship quality on customer retention: A critical reassessment and model development. Psychology and Marketing, 14(8), 737-764.

[17] Ho, C., \& Lee, Y. (2007). The development of an e-travel service quality scale. Tourism Management, 28, 14341449 . 
[18] Internet World Stats. (2010). Internet world stats usage and population statistics. Retrieved March 20, 2007, from http://www.internetworldstats.com/stats2.htm

[19] Jeon, M. (2009). Conceptualizing web site quality and its consequences in the lodging industry. International Journal of Hospitality Management, 22(2), 161-175.

[20] Jeong, M., \& Lambert, C. U. (2001). Adaptation of an information quality framework to measure customers' behavioral intentions to use lodging websites. International Journal of Hospitality Management, 20(2), 129-146.

[21] Kaynama, S., \& Black, C. (2000). A proposal to assess the service quality of online travel agencies: An exploratory study. Journal of Professional Services Marketing, 21 (1), 63-89.

[22] Kiang, M. Y., Raghu, T. S., \& Shang, K. H. (2000). Marketing on the Internet - who can benefit from an online marketing approach? Decision Support Systems, 27, 383- 393.

[23] Kim, W., \& Lee, H.Y. (2004). Comparison of web service quality between online travel agencies and online travel suppliers. Journal of Travel \& Tourism Marketing, 17(2/3), 105-116.

[24] Kumar, N., Scheer, L. K., \& Steenkamp, J. E. (1995). The effects of supplier fairness on vulnerable resellers. Journal of Marketing Research, 32(1), 5-65.

[25] Lagace, R. R., Dahlstrom, R., \& Gassenheimer, J. B. (1991). The relevance of ethical salesperson behavior on relationship quality: The pharmaceutical industry. Journal of Personal Selling \& Sales Management, 11(4), 39-47.

[26] Lages, C., Lages, C. R., \& Lages, L. F. (2005). The RELQUAL scale: A measure of

[27] Lin, C.-P., \& Ding, C. G. (2005). Opening the black box: Assessing the mediating mechanism of relationship quality and the moderating effects of prior experience in ISP service. International Journal of Service Industry Management, 16(1), 55- 80.

[28] Locklove, C. H., Patterson, P., \& Walker, R. H. (1998). Services marketing. Sydney: Prentice Hall. relationship quality in export market ventures. Journal of Business Research, 58(8), 1040-1048.

[29] Loiacono, E., Watson, R., \& Goodhue, D. (2002). WebQualTM: A measure of web site quality. In Evans, K., Scheer, L. (Eds). Marketing educators' conference: Marketing theory and applications. 13, 432-437.

[30] Madu, C. N. \& Madu, A. A. (2002). Dimensions of e-quality. International Journal of Quality \& Reliability Management, 19(3), 246-258.

[31] Moorman, C., \& Zaltman, G. (1992). Relationships between providers and users of market. Journal of Marketing Research, 29(3), 314.

[32] Odlyzko, A. D. (200). Satisfaction is nice, but value drives loyalty. Marketing Research,11(1), 20.

[33] Oliver, R. (1997). Satisfaction: A Behavioral Perspective of the Consumer. NY: McGraw-Hill.

[34] Oliver, R. L. (1999). "Whence customer loyalty?" Journal of Marketing, 63(4), 33-44.

[35] Rachjaibun, N. (2007). A study of antecedents of e-relationship quality in hotel websites. Unpublished doctoral dissertation, Oklahoma State University-Stillwater.

[36] Rauyruen, P. (2007). Relationship quality as a predictor of B2B customer loyalty. Journal of Business Research, 60(1), 21.

[37] Sanchez-Franco, M., \& Roldan, J. (2005). Web acceptance and usage model: A comparison between goal-directed and experiential web users. Internet Research, 15(1), 21-48.

[38] Singleton, J ., Straits, B. C., Straots, M., \& MaAlister, R. j. (1988). Approaches to Social Research. New York: Oxford University Press.

[39] Storbacka, K., Strandvik, T., \& Gronroos, C. (1994). Managing customer relationships for profit: The dynamics of relationship quality. International Journal of Service Industry Management, 5(5), 21.

[40] Szymanski, D. M., \& Hise, R. T. (2000). E-satisfaction: An initial examination. Journalof Retailing, 76(3), 309-322.

[41] Wimmer, R.D. and Dominick, J.R.(2003). Mass Media Research ( $7^{\text {th }}$ ed.) Belmont, CA: Wadsonworth /Thomson Learning, Inc.

[42] Wolfinbarger, M. \& Gilly, M. (2003). eTailQ: Dimensionizing, measuring and predicting Etail quality. Journal of Retailing, 79(3), 183-198.

[43] Wray, B., Palmer, A., \& Bejou, D. (1994). Using neural network analysis to evaluate buyer-seller relationships. European Journal of Marketing, 28(10), 32-48.

[44] Yang, Z., \& Jun, M. (2002). Consumer perception of e-service quality: From Internet purchaser and non-purchaser perspectives. Journal of Business Strategies, 19(1),19-41.

[45] Yang, Z., Cai, S., Zhou, Z, \& Zhou, N (2005). Development and validation of an instrument to measure user perceived service quality of information presenting Web portals. Information \& Management, 42(4), 575-589.

[46] Yoo, B., \& Donthu, N. (2001). Developing a scale to measure the perceived quality of an Internet shopping site (SITEQUAL). Quarterly Journal of Electronic Commerce, 2(1), 31-46.

[47] Zeithaml, V.A., Parasuraman, A., \& Malhotra, A. (2002). Service quality delivery through web site: A critical review of extant knowledge. Journal of the Academy of Marketing Science, 30(4), 362-410. 